\title{
Demons, Devils, and Witches in Pentecostal Port Vila: On Changing Cosmologies of Evil in Melanesia
}

\author{
Annelin Eriksen and Knut Rio
}

Introduction: Pentecostal Port Vila

Port Vila, the capital of Vanuatu, is a small but growing Melanesian city. In the last decade, an increasing number of migrants from around the archipelago have arrived to take part in the country's growing tourist industry-as taxi-drivers, in hotels or as domestic workers, cleaners, or shop assistants. Many migrants also arrive without work, and spend periods of time just "hanging around" or as "SPR - sperem pablik rod" as they are locally phrased, before most of them go back to their island or find some low-income work. The city center itself is dominated by tax-free stores, restaurants, coffee bars, and local handicraft markets, a generally modern sphere of consumerism and wealth that is not really available to most ni-Vanuatu. Few people of Vanuatu origin live in the

\footnotetext{
A. Eriksen $(\bowtie) \cdot$ K. Rio

University of Bergen, Bergen, Norway

(C) The Author(s) 2017

K. Rio et al. (eds.), Pentecostalism and Witchcraft, Contemporary Anthropology of Religion, DOI 10.1007/978-3-319-56068-7_8
} 
city center itself. Some of the most centrally based residential neighborhoods and gated communities are almost exclusively settled by white ex-pats, who operate on the managerial levels of the tourist industry, as advisors or NGO-workers. The migrants from the different islands of the country live in semi-formalized neighborhoods at the outskirts of the city center. From the perspective of a village-dweller in the rural areas, these urban settlements are somewhat strange and alien places. This is also often pointed out in urban discourses: Vila $i$ difren or Vila $i$ tanem kastom ("Port Vila is a different place" or "Port Vila changes traditional life"). As a small city, it is not just a big composite village or a more compact version of a Melanesian place. Whereas in a village context kinship systems, avoidance rules, ceremonial obligations, marriage patterns, and agricultural routines order everyday life, in the urban neighborhoods people from different islands live side by side with different languages, different kinship systems, and marriage principles, and social life is regulated by completely different regimes. The workplaces, the playgrounds, health services and schools, the different settlements and their numerous kava-bars ${ }^{2}$ and stores, the many different church communities, ${ }^{3}$ all form a new order of life. What matters is not that the city brings people much closer in terms of access to the market, to the state or to modernity, or that people abandon their kinship awareness or relational obligations-but that city life represents a unique situation with other social parameters and values (see also Mitchell 2011). It has other spiritual, moral and ritual bearings. The city of Port Vila can, therefore, be understood as "another world," and we argue that we might see this as a Pentecostal world.

Since 2006 we have done research on Pentecostal churches in Port Vila. ${ }^{4}$ In the first phase of this research, we were eager to define what kind of churches were Pentecostal and which were not. More recently, however, we have found that this was not necessarily the most useful way to operate. It has recently dawned on us that it might be more revealing for our understanding of Port Vila if we viewed the whole city as a Pentecostal context (see Eriksen 2009a, b; Eriksen forthcoming). First, because the wave of what we might call charismatic and spiritual influence affects the Catholic, the Presbyterian, and the independent churches as much as it does the self-declared Pentecostal churches. Thus, the practices by which we often identify the Pentecostal faith, such as speaking in tongues, being slain in the spirit, and spiritual healing, are now as much a part of, for instance, the Presbyterian register as 
they are the Pentecostal (see Bratrud, this volume). Second, and even more importantly, the core ideas and perspectives that emanate from the Pentecostal worldview are not just relevant for a "religious" context. Rather these ideas and practices are structuring everyday life in a total sense. People relate to the presence of the Holy Spirit everywhere; as much in the grocery store where there is a healing room in the back, as in the market where women heal or talk about healing in-between selling fruits and vegetables, or in the schoolyard where secondary school students talk about their experience of trance and encounters with the Holy Spirit. But Pentecostalism has a total presence also for the nonconverts who relate to the claims, observations, and stories of spiritual and divine presence. In this chapter, we claim, in accordance with the general argument of this book, that an escalation of witchcraft and sorcery activity is integral to this Pentecostal world (see also Newell 2007). Furthermore, we argue that in order to understand the reason for the escalation, we need to understand the emergence of what we will call a new cosmology of evil. Thus, in this chapter, we present ethnographic glimpses from fieldwork in 2010 and 2014, when we experienced an intensification of cases of witchcraft and sorcery and the issue of spiritual insecurity in Port Vila.

\section{A City in Need of Protection}

At the same time as we were going around the city to document the many new charismatic so-called "break-away churches," in the spring of 2010, we also became aware of numerous allegations of mysterious illnesses, magical robberies, and suspicious deaths (see also Rio 2011). This was a period of intense attention to new forms of magic and sorcery, articulated in conversations between people in the streets and settlements, in kava-bars, in churches, and in the media. As much as possible we tried to get close to the events and tried to find people who were involved. We got partial accounts of these happenings, some from the pastors we interviewed, some from old friends, and some from newspapers reports. We do not have space here to fill in the total picture, but we will try to convey a few snapshots of this many-sided situation.

Just after we arrived in January of 2010, we were talking to one of the Pentecostal pastors about politics and the presidential election that had just taken place in the fall of 2009. He was eager to tell us that in the build-up to the election the Port Vila Council of Churches had decided 
to run a spiritual campaign, in order to "protect the nation" at this critical point. The pastor and his fellow preachers from other churches had surrounded the city with spiritual protection. They set up prayer sites at the geographical points that marked the city's boundaries-one on Ifira Island to the east, one close to the national airport in the north, one on the Bellevue hill to the east and one on Pango Point to the south. This was to ensure that "evil" and "dirt" and "corruption" should not enter into the election, and the league of pastors with their intense prayer and spreading of holy water hence upheld the moral integrity of the city during that election weekend. At the same time, all the people in the various churches around the city also joined in prayer directed toward the city as a circumscribed realm. The people of the churches thus fenced in the city at this liminal moment.

It should be noted that whenever political decisions are being made people in Port Vila suspect that magic is also being used to influence politicians as well as voters. One of the pastors we talked to added that every first Monday of each month, the Prime Minister prayed in his house with two or three chosen pastors from different Pentecostal ministries. They prayed for upcoming sessions of the Parliament if there were unrest, fragmentation, or motions of no confidence; they prayed for the progress of the national economy; they prayed for the success of the building of a new road, or they prayed for better health and less sorcery and evil. These are all things that threaten to harm the benevolent nation by continuously exposing it to the powers of fragmentation and inequality.

Here, we are already touching on what we imply when we refer to Port Vila as a Pentecostal city. It is a space that is held out by its citizens as a special, almost holy realm, and a personified realm that is like a person in need of protection, care, and leadership. It might easily be corrupted by evil, through the influence of overseas businessmen or missionaries, or from ancestral traditions brought in from the outer islands, but also from within the city itself in terms of envy, selfishness, and greed. These corruptive and disruptive influences are the foundation for the "Pentecostal witchcraft" (see Newell 2007), that the many new churches around Port Vila are focused on. They define this realm very widely and populate it with "demons," "spirits," (devil in Bislama), "black magic," "poisoning" with herbs, and sorcerous remedies such as $s u$ (instruments of homicidal sorcery). When there is an illness in a household or in a neighborhood people often speculate if a $s u$ or other magical remedies such as human ashes or bones of stillborn babies are buried in the ground 
or hidden behind the house of the victim. The new "healing ministries" specialize in spiritual warfare raids into such neighborhoods to clean them out and to detect such remedies. Our student Hildur Thorarensen, also did fieldwork in Port Vila in the spring of 2010, on the Survival Church in the neighborhood of Freswota. She describes in detail such a spiritual warfare raid in her Master Thesis. A family came to the church asking for help because they were afraid there might be some sort of nakaimas (sorcery) in their house. There has been a lot of suspicion of black magic going on in that street, and four persons were said to have died in mysterious ways. The members of the church prepared "spiritual warfare," and one night the congregation walked together to the cursed house, the pastor and his wife, some of the older founders of the church, some of whom were "Prayer Warriors" and one was a "Prophetess," in addition to some choir girls and boys from the Youth Group. They were met by the family, sitting quietly on a mat inside their corrugated iron house. The congregation stopped outside, and the Pastor started giving instruction for the ceremony. Most were to stand in the back singing, some were to pray out loudly. They were now watching for something to react to the singing or praying, a rat, a gecko or an insect, since that would be a 'devil'. Members of the group were to give notice or try to kill it immediately. The Prophetess, the Pastor, and the Prayer Warriors went inside the house and started praying, while the rest of the congregation stood outside and began to sing. Thorarensen writes:

Suddenly the Prophetess came running out of the house, her eyes are closed and her arms are shaking; a usual sign of her being possessed by the Holy Spirit. The Prayer Warriors and the pastor follow right behind her, still praying loudly, as the prophetess runs away from the house and down a path. After them follows the family, and finally the rest of us, still singing. At this point a girl from the Youth Group whispered to me that the Prophetess has now felt the presence of evil spirits, and that she has begun chasing them. The chase continues up and down narrow paths around the neighboring houses at such an increasing pace that in the end we are all running, and finally uphill towards some banana trees. The Prophetess and the Prayer Warriors start hitting the trees, chopping them down to the ground with their bare hands. Some Prayer Warriors are still praying, and one of them is angrily shouting "Out, devil! Out”. (Thorarensen 2011:91-92)

What Thorarensen describes here was going on in many parts of the city. These local events were about protecting neighborhoods that were 
marked by evil spirits, either as outside influences or internal corruptions. This particular form of spiritual warfare also defines the general measures taken for protection, being as relevant on the level of the nation and the capital as inside the household and toward the individual.

During our explorations of Pentecostal Port Vila in 2010, we also talked to some of the members of the Melanesian Brotherhood, an action-oriented branch of the Anglican Church that is dedicated to sorting out spiritual, demonic, and sorcery-related problems. They wear black robes as uniforms, and all brothers have a powerful walking stick that is highly respected and widely reputed to perform miracles. The brothers gave us accounts of two episodes that had taken place in the last months. The first one concerned one of their members who had died suddenly after leaving Port Vila for his home island. As part of their spiritual investigation of what they perceived to be a suspicious murder, they had traced his movements during his last days in Port Vila. They were convinced that he had been victim to a sorcery attack in Port Vila, and by following "spiritual leads" around town they were on the track of the killer. Their search became a detailed spiritual mapping, where they found hotspots for evil forces in certain locations of the city and tried to divine these places as part of the investigation. They had formed a complete picture of the deceased person's trajectory toward his death and the various human and spiritual agencies involved in it. They had concluded that their brother was already dead in the Port Vila harbor when he set his foot on the ship that was to take him to his home island. He had only appeared to be still living on board the ship and when going ashore at home two days later-because he was put in a zombie state by the sorcerers who had killed him in Port Vila. As a result of this killing, the Melanesian brothers now considered themselves to be implicated in a spiritual war. They were under attack from a league of sorcerers that they believed wanted to control the city.

Another case that had occupied them in this spiritual war concerned a young man who had become a "vampire" (fampa in Bislama). The vampire was first held captive by the chiefs in his neighborhood, and the Melanesian Brothers were called in since they were the only ones who could come close to him and detain him. He had superhuman strength and they had to ritually pacify him, they told us. This was a young man in one of the squatter settlements who had been transformed into a phantasmagoric creature, half man half animal. The brothers had deduced that it had all began because the boy had been smoking a lot 
of marijuana and living an outgoing and "wild" life. In their reasoning, they pinned down the start of his transformation to one particular night when he had smoked so much marijuana that he had become completely unconscious. The Melanesian Brothers believed that it was at this time that a witchcraft creature had entered his body and that this creature was now controlling him. He was publicly exposed as a vampire when his girlfriend had to go to the hospital because she lost her strength, and the doctors confirmed that she was low on blood. At the hospital, she had told her family that her boyfriend had regularly been sucking blood from her (see also Rio 2011: 57). When reported in newspapers, TV, and gossip, the case caused much alarm and confirmed the widespread worry about the spiritual siege that the city was under. When we talked to the chiefs of the vampire's settlement they also emphasized the special role of the Melanesian Brothers. It was because of them that they had managed to restrain him, to pacify his powers and liberate him from the grasp that the witchcraft creature had over him. After he had been treated by the Brothers, the boy was sent to prison, but he was released after a while since he collaborated with the police and gave up the names of the people who were behind the witchcraft. Again the idea-equally widespread among the Brothers, inside the system of law as well as on the streets of Port Vila - that there was a league of sorcerers that wanted to control the city, and that anyone and everyone would be victim to their superhuman powers.

We experienced that these circumstances were new and surprising for people in Vanuatu. Not only because it was so widely publicized in the news, and since it implicated the Melanesian Brotherhood, the police and courts of law in new alliances around the occult scene, but also because people could not recognize in it any traditional forms of spirit possession, sorcery or witchcraft. On national television, it was said that a "White millionaire" was behind the league of criminals and that he had supplied them with magic that originated in the Western world. It was added that as the boy drank blood from his girlfriend, he would become a white woman. Reportedly, the special tooth that he used for sucking blood had been an instrument from African magic. All sorts of mixed rumors and speculations of this kind arose, and people pointed out to us that it was as if the city was under attack or that their city security had been breached. Despite the intensive measures for protection set up by the churches and healers, unknown occult powers of evil were on the loose inside their own city. 
Another case that got our attention at the same time was a court case around police brutality. In 2009, the police had launched a campaign called "Operation Clean-Up," where the aim was to recapture a group of escaped prisoners. One of the captives was probably killed during the man-hunt, although never found, another was killed during interrogations. He suffered " 32 different injuries to his head, chest, abdomen, right upper limb, left upper limb, right lower limb, left lower limb, and back" (Daily Post, March 5, 2010). The violence of the operation shocked the urban population as they read about it in the newspapers. Because of this extremely violent death, an Australian coroner was appointed to lead an official enquiry into its circumstances. During his work, it became clear that members of the police sabotaged his work and even threatened him (Dawson 2010: 33). Police officers excused the death by saying that "the deceased was not looking normal, being overly aggressive and under the influence of drugs" and that it was the drugs that had killed him (Dawson 2010: 17).

Generally, it seems to us that in this case, the intense activity of detecting evil in the pentecostalised protection of the city spilled over into the state apparatuses in a very brutal and direct way. We knew from our visits to the healing ministries and new church congregations that these specific members of the police force were eager participants in one of the new international charismatic churches in town. There were thus clear parallels between "Operation clean-up" and Pentecostal crusades, spiritual warfare, and campaigns for a moral cleansing of the city. The people performing the latter were also the chief agents of the former (see also a comparative case from Fiji, Trnka 2011). The newspaper writings as well as the coroner's report revealed the police understanding of the prisoners as "sinners," due to their breach of a moral code around rape, alcohol, and marijuana. This breach of a moral order and thereby the tainting of the city's larger moral integrity provided the energy with which the police found the escaped prisoners, the violent punishment as well as their treatment of the foreign Coroner who was also seen to be invading and trespassing into the moral order of the city. In this latter case, we can see the ways in which also the state becomes part of the totalizing Pentecostal context.

The issue of marijuana ran through many of the cases and much of the talk of the city. We became painfully aware of this in relation to another situation that came up during our stay. A close relative of the family with whom we had stayed during our previous fieldwork back to 1995 was 
seriously ill. The young man had been working as crew on one of the cargo ships that deliver goods to the outer islands, and his father, himself a member of a small independent church in one of the settlements, told us that for the last few years his son had been smoking a lot of marijuana. This drug, more than alcohol, in these circles of Port Vila, is seen to draw evil forces to a person, as the intoxication leads to unconsciousness and change of mind. Seemingly, this state of mind implies a corruption of the person that is very much a target of Pentecostal warfare in Port Vila. In the case of the young man, it also became clear why. The problem with marijuana is that it blocks one's capacities for communicating with God and the Holy Spirit. A clear mind and alert perception are required to be a good Christian. At one point we were invited to see the sick man and his family on the outskirts of the town. He was lying on the floor, trembling and delirious. His father and mother and other members of the family were sitting around him, praying. They had been doing this continually for a few days, each taking their round so that the prayer could be kept up around the clock. But, as they explained, it couldn't be fully effective, since the boy himself wasn't able to communicate with God because of his delirious state. As in the case of the vampire above, the problem was that the marijuana had taken hold of him and blocked his abilities for communicating with God. It turned out in our later communications with the father that when he said "marijuana," he meant this in a broad sense. It was also a form of sorcery (posen in Bislama) that came with the marijuana that had put him in such a delirious state. "It had entered his blood," he said, so that there could be no cure for it. His father speculated that the marijuana lifestyle on board the trading ship had made him an easy target for the sorcery from one of the outer islands. The boy died a couple of days later. At the hospital, they told us that he had cancer in his blood and that he couldn't have been helped by doctors or medicine.

These few glimpses of rumors, concerns, and activities related to witchcraft and sorcery in Port Vila in 2010, reveal the moral warfare that was taking place at all levels of city life. When we argue that Port Vila is a Pentecostal city in a broad sense, we imply not only that the city sees a growth in Pentecostal, or Pentecostal-like congregations, but that concerns and activities which we identify as Pentecostal, such as spiritual warfare and healing, take place at all levels of social life (in the police force, in family life, in prayer circles, in politics, in media, etc.). These activities involve an intense occupation with where evil comes from, 
cleaning it up, and providing protection from it. Let us now turn closer scrutiny to what this concern with evil is about.

\section{Toward an Anthropology of Evil in Port Vila}

In this Pentecostal world the distinction between good and evil, between prayer and sin, between past and present is paramount. It is the world where binaries are center stage. Pentecostalism produces this black and white world. The order that emerges in the neighborhoods of Port Vila displays a very specific historic and cultural dynamic, but it has also much in common with places like Luanda in Angola (see Blanes, this volume) or Kinshasa in The Democratic Republic of Congo (see Pype, this volume), or for that matter Guatemala City (see O'Neill 2010); anywhere in the world where Pentecostals engage in "world-making and world-breaking" (see Jorgensen 2005).

Evil is often understood in a personified form in Christian thinking. Evil takes the form of the devils and demons. Surprisingly little is found in the Bible about the devil, but it is important in the teaching of particularly Protestant thinkers and theologians, as Calvin and Luther (see Meyer 1999; Russell 1986). As has been pointed out by historians of religion, theologians, and anthropologists alike, evil has a specific significance in Christian cosmology. This is true both for its European development (see Russell 1986, 1987) and in missionary activities in for instance Africa (Meyer 1999; Englund 2004) in Oceania (Barker 1990; MacDonald 2015) and elsewhere in the global south. One might say that the concept of the devil creates a phantasmagoric space where crucial world-making processes take place.

In spite of this, there has been little focus and discussion about the role of this conception of evil and of the devil, as Christianity has arrived outside of the areas where it has had its historical origins. However, with the rise of Pentecostalism, ethnographic descriptions of articulations of the devil have emerged. Meyer, working among the Ewe in Ghana (1999), has argued that Pentecostals became successful exactly because they took the devil, the personified form of evil, seriously. Ewe Christians who had heard from established Presbyterian missions that Ewe ancestral spirits were diabolical and proof of the devil's work, were caught in a paradox; if their heathen traditions belonged to the devil, how could one be free from them? Free from one's past and what was understood as the devil's work? With the Pentecostals' focus on deliverance, a new tool 
to deal with the devil was introduced. Barker (1990) has pointed to the significance of the specific discourse on evil for the Maisin of Papua New Guinea. In the encounter between the missionaries and Maisin ideas of sorcery and witcheraft, a space for a re-articulation of Maisin spiritual ideas opened up. Sorcery and witchcraft became an integral part of Maisin Christianity as a representation of evil, much in the same way as Meyer has described it for Ghana.

Returning to Port Vila, one of the key aspects of life in this Pentecostal context is the new significance of evil. As we have seen, social life in Port Vila neighborhoods rotates around ideas, speculations, worry, and preventive action against very tangible and highly present forces of sorcery and demons. Spending an afternoon in any household in one of these neighborhoods one is quickly drawn into this world: in gossip about the neighbor, in discussions about the cause of someone's sickness, or in getting advice about which path to take to the grocery store, or which grocery store to go to in the first place. There is an overwhelming presence of an idea of spiritual danger, which is just around the corner, ever-present and threatening (see also Strong, this volume, where "witches are everywhere").

In our most recent fieldwork in 2014, we worked with a selection of healers, from different denominations, who all work though the Holy Spirit. Although the idea of evil is present in everyday discourse, the healers are more articulate than most people about the nature of evil. The word "evil" itself is not so current in these narratives. It is more talk of "demons," "devils," "poison," or "dirty," "no good" things. The healers develop specific images that they use in their communication with patients to alert them to danger. One of the healers pointed out that the work as a healer is first and foremost about giving protection to people from the roaming danger, a constant presence and threat of malignant spirits always lurking in the vicinity. She and other healers talk about Port Vila as "a jungle." Therefore healing is not only about helping people who are sick, but also doing work in the neighborhood to prevent the moral conditions that cause sickness, death, and misfortune. Because evil spirits are all around, this is constant work, a nonstop effort. By looking at the ways in which the healers talk about the jungle of bad things and how it operates in this world, it is possible to give a portrait of what evil looks like in this context. Understanding what evil is, is also the key to an understanding of how a social order emerges, and thus, as we will show, what the effects of Pentecostal witchcraft are. If Pentecostalism is 
a machine producing Manichean binaries, and the binary between good and evil is the most significant, this fundamentally shapes social life. The nation of Vanuatu, the city of Port Vila, the specific neighborhoods, and household, as well as interiors of persons, are spaces where evil is to be kept at a distance. With tools like discernment, prayer, healing and spiritual warfare, protective boundaries against evil are erected. These boundaries need constant ritual work and maintenance. Thus, there are mainly three aspects of healing; first, seeing (or "discernment" as the healers call it) where evil is located and, second, casting out the demons and banishing them from the perimeters, and, third, erecting and keeping boundaries between the good and the evil. The most effective healers, and those with the most prominent reputation have different versions of what they call the gift of discernment. They have x-ray sight, they can see in dreams, or they receive specific sensations when evil approaches (as a throbbing pain in the forehead or in the palms of the hands). These abilities mark the healers as distinct from others. Most people cannot see, nor feel, where and how the evil will approach. Therefore most people are dependent on the healers for protection.

Also in Port Vila evil takes a personified form. "Demons are all around us," one of the healers told us. When she walks the streets of the city center in Port Vila, she does not see the faces of ordinary people passing by. Rather she sees the grotesque faces of demons. She can see what others cannot, and even the people who are possessed by evil demons might not know it.

The healers are often just known as "women who pray." 5 One of the ways in which one can protect oneself from the demons is through prayer. If one regularly attends prayer meetings, organized by the healers, one can achieve a certain protection. However, very often, people neglect to "trust God," and for instance listen to advise given by wellmeaning relatives to drink herbal brews, to wear specific protective items to guard against specific magic or to heal specific symptoms. According to women who pray these remedies open the way fully for demons: these are the very media through which the demons enter the body and, ultimately, the soul.

Sorcery, or posen and nakaimas, can appear in many different versions, but the healers often detect it as material or territorial technologies which are instantiated consciously by someone to inflict harm on someone else. For instance, this can be a parcel made from specific bones and ashes planted outside a house to inflict harm on those living there. One 
of the healers we worked with has the gift of X-ray sight, and she can see right through persons or materials. She is also a popular healer for businessmen who are afraid of competitors who might target them with nakaimas to drive them out of business. A healer is therefore often asked not only to bless new businesses, and thus protect them, but also, regularly, to "scan" the places for sorcery. The healers adjust their treatment to the specific kind of evil that is in question. If a person is possessed by a demon, the healers need to identify the medium though which the demon has gained access to the patient's body. If the symptoms are different, for instance just trouble at work, in marriage or politics, the cause might not be a demon but nakaimas. However, the healers often articulated that the differences or nuances between instruments or causes didn't matter to them. Whether an affliction was caused by ancestral spirits, urban demons, overseas magic or local sorcery items it still had the one and same origin and cure. It was the result of an opening or a crack in the moral constitution of the person-a crack that had allowed the evil forces inside the self - and the crack had to be closed by the Holy Spirit through discernment and prayer. In Port Vila evil is becoming an absolute phenomenon; there are no "grey" areas. There are no forms of sorcery or witchcraft or demons that are only slightly evil. And the question of evil must be located to the integrity of the person affected by it. As an extension of the argument forwarded by Robbins in his article on Pentecostal ritual (2004) we should add that probably the most important factor for explaining the popularity of Pentecostalism must be the role that healing rituals and rituals of discernment play for redefining an entirely new field of "spiritual powers" around the individual person. The cleansing of neighborhoods, cities or nations-where the ritual is taken out of the church building and into the streets, brings about the change that is the Pentecostal revolution. This is what Robbins calls "the Pentecostal promotion of ritual as a mode of sociality" (Robbins 2009: 63). People leave behind the church building and its ritual services and instead cast the everyday as a platform for generalized ritual activity. By ritual, we here imply a form of routinely engagement with forces that lie beyond the observable and tangible, that pertains to the sorting out of invisible forces that have penetrated into persons, things, or relations. The object of the rituals is the discernment of these invisible influences, their cleansing or casting out and the reestablishing of the normality of the situation. In Port Vila everywhere you go you are subject to attacks from these spiritual influences, and so the city is also becoming obsessed 
with purity on all levels. The sources of evil might be from ancestral spirits from your homeland, it might come from foreign products like the canned food in the Chinese stores, it might enter through your mobile phone or through television or the Internet, or it might arrive in the form of intentional sorcery in the form of magic parcels of sorcerous remedies planted under your porch or in your garden.

What is new in the situation is not that people in Port Vila are under the influence of destructive forces, and, as elsewhere in Melanesia and the rest of the world, people in Vanuatu have probably always taken very seriously the negative influence from other human and non-human beings. What is new in the Pentecostal circumscription of social life in Port Vila is both that people subject all afflictions to a unitary language of Pentecostalist warfare and healing and that they perceive their life, wellbeing, and personhood to be primarily related to protection and a hygiene of spiritual cleanliness. This cleanliness is no longer associated with specific customary taboos, avoidance of certain relatives, nor achieved through measures of generosity and gift-giving. It is no longer possible to keep ancestral spirits at a distance by performing initiations or sacrifices. Instead, the ancestral spirits are now purely penetrative agencies who roam free in the urban setting, in accompaniment with all the other destructive agencies that cause danger to person and community. The Pentecostal way of life is a form of constant warfare, which also results in the direct attacks on the specifically local diversity of spiritual forms. Pentecostalism invests a lot of energy into this local diversity but only in order to attack it and try to overcome it with its own form of universalism. In the recent decade in Vanuatu this has also resulted in violent attacks on accused witches, and sometimes even the murder of witches (see Rio 2011; Bratrud, this volume).

\section{Overturning a Traditional Vocabulary}

As noted in the introduction to this volume the vocabulary of sorcery and witchcraft is always written into histories of translation and social change. Similarly, posen and nakaimas in Port Vila are concepts that reproduce and reinvigorate and sometimes overwrite former usages. They are Bislama words that have absorbed in them especially the life in the city and the danger of being exposed to other people's traditions. They become key words for sorcery and witchcraft which are practiced in different ways around the many islands of Vanuatu. Although the words 
in Port Vila are now unified around ideas of evil, it is not necessarily so elsewhere in Vanuatu. On the island of Ambrym where we did fieldwork previously, in the 1990s, abiou as a local concept was understood and explained in a very different way. Most importantly, the Ambrym concept of abiou was not necessarily understood as evil (see Rio 2002; Rio and Eriksen 2013), and as it has also been the case in the rest of Melanesia, sorcery was often a legitimate form of governance and control (see Stephen et al. 1987; Dalton 2007). Although Ambrym has had a long history of Christianity, beginning with the first missionaries in the latter part of the nineteenth century, the binary notion of good and evil had lesser significance for the concept of abiou. Catholicism, Presbyterianism, and SDA forms of Christianity had an influence on people's lives and in particular on gender relations and notions of equality (see Eriksen $2005 ; 2008$ ). Social life was structured on the continuity of kin relations and on the value of connectedness, but not so much around good and evil ${ }^{6}$. In this discourse of abiou, it was not easy to determine who the guilty one was since spiritual powers were per definition ambiguous, ephemeral, and hard to determine. The figure of the diviner was determining cures based on relational skills and herbal knowledge and not so much judging either victim or sorcerer on moral grounds. This is in line with many accounts of Melanesia, where we have learned that sorcery and witchcraft were underlying structural conditions of relations and an ever-present potential of social relations (Hocart 1925; Malinowski 1926; Layard 1930; Fortune 1932). Sorcery and witchcraft were heterogeneous and multivocal aspects of ordinary intimate relations (see also Geschiere 2013; Stroeken, this volume). Abiou on Ambrym worked in a clearly non-personified form; it was neither caused by a specific, unitary person nor did it attack a unitary victim as much as his or her relational capacities. It was dangerous, something to be aware of and be careful about, but at no point related to the moral qualities of the inner unitary person, classified as "evil" and opposed to "the good". We can thereby say that there is a long stretch, and an ontological rupture, between the world of Ambrym abiou and Port Vila nakaimas or demon.

In Port Vila in its Pentecostal state, evil is becoming personified not only in the sense that the devil, demon, witch or sorcerer is a person who wants to harm you, but also in the sense that the result of evil is the eradication of the person. In other words, the cause of evil is personified but the target of evil is also the inner self. Thus, when the healers work, they need not only to identify the cause of the patients' suffering 
(the form of corruption, who or what has caused it etc.), but also to restore the person. When a person has experienced becoming possessed by a demon, the healer needs to not only rid the body of the evil, but also to restore the boundaries of the person. One might say that in order for the moral person to appear healed after possession, the person needs to be reconstituted through the reestablishment of the active, conscious self. In cases of nakaimas sorcery and demon possession, this is what the healer does; she reestablishes an internal subject in active possession of one's own body and mind (see also MacCarthy, this volume).

Demons threaten the subject by extinguishing the internal self. That is, the demon (also in the form of marijuana) is a force that captures the consciousness of the person and takes over the will, the agency and the outlook on the world. It transforms the person into a desiring and craving figure-wanting what others retain; therefore envy is often the sign of evil. A person possessed by a demon, or a person with access to nakaimas, is fueled by envy; for other people's wealth, but also for other people's personhood; for their "inner selves," as one of the healers expressed it. In order to protect oneself against this roaming evil one thus needs to always be conscious of oneself; of whether one's actions are in line with God, or following the words of God. In order to trust God and to pray, however, one needs the intact "inner self"; if not, one cannot be "saved" from evil. In other words, healing demands of the person to be conscious (i.e., "awake"), to be able to engage consciously with God, as we saw above. Thus, the healer addresses a field of relationships that are entirely contained inside the person-in the interplay between being awake and being asleep, conscious and unconscious, alien and authentic, healing and corrupting, and good and evil. It is this binary struggle that gives energy not only to the healing process but to the social dynamics of this Pentecostal context; it is from these binaries that the fundamental social mechanisms emerge and shape the constitution and governance of both the person and the household-and, one might argue, the city and the nation.

\section{Trust IN GoD}

So far we have argued that the binary distinction between good and evil is fundamental for social life in Pentecostal Port Vila and for Pentecostal witchcraft in particular. We have also argued that evil takes a personified form and it attacks the integrity of the person, of the neighborhood and 
the entire city. For instance, one of the healers we worked with (in 2014) had identified a so-called "clever", a man with particular knowledge of herbal medicine, as a person who had inflicted harm on others. She had repeatedly noticed that the neighborhood he was living in had been particularly inflicted with sorcery. She also knew the cause. She knew that this older man, who had for long been respected for his particular knowledge of traditional medicine, now gradually was losing his position. Few people consulted him anymore, as healers who worked with the Holy Spirit had become more popular and more accessible, and as the new churches and the new style of worship had become more widespread. After a particular incident, where she had detected a particularly malignant form of sorcery in this neighborhood (bones of a dead baby buried at the entrance of a house), she decided that he had to be named. There is a lot of evidence here, she told us. Not only has almost all his neighbors been affected by his black magic; some had become sick, others had domestic problems, and some had problems at work. Even more significant as evidence, however, was the fact that his wife had an ulcer on her leg that would not heal. She had heard this from a person who had recently visited the house of the old man and his wife. The wife had been sitting on a chair nearby as the visitor consulted the kleva. He had seen that the wife had been hiding a sore under a calico. This was no ordinary sore; it was big, open, and smelly. According to the visitor, the sore revealed a leg that was in the process of decomposing. In itself, this is evidence, the healer pointed out. The sore reveals the presence of evil. The sore is evidence that the so-called "clever" cannot heal her. Furthermore, it is proof of his lack of will to seek real help; to be healed through the Holy Spirit. Lastly, he had good reason to be envious; as he was losing his ground as a knowledgeable man.

There is a pattern to the location of nakaimas in Port Vila: If people are poor, miserable, sick or victims of bad luck, they have all the more reason to be envious of others. The feeling of envy attracts evil through demons. Dealing with herbal medicine is proof of the lack of trust in God and thus the proximity to evil. Since God is always good to the righteous he will always give blessing and healing to those who deserve it. Every person is responsible for his or her own commitment to God. It is thus very likely that people who suffer from poverty or illness, like this man and his wife whose wound would not heal, have actually welcomed evil and not committed themselves to God. 


\section{Conclusion}

There is zealous sorting out of the problem of sorcery and witchcraft taking place in the neighborhoods of Port Vila. Many of the churches are designed for exactly the purpose of healing and exorcism, and they attract followers because people come to know them as "healing ministries." Every church and every congregation have several women who specialize in different forms of healing, exorcism, and discernment. In similar ways to what is going on, say, in South Africa or Nigeria, these churches move into suburbs with what they call "spiritual warfare" and approach, clean out or exorcise whole neighborhoods for signs of witchcraft. In the jungle of evil, the healers can see what others cannot, and help in the process of creating order by discerning between good and evil, and thus between God and the devil. This cosmology of evil rests on a kind of "absolutism," of a clear distinction between black and white, clean and unclean, good and evil. This Manichean form of reasoning also triggers social activities that pursue this logic: the logic of warfare, of "cleaning up" and the erection of protective boundaries. Healers are essential in this work, but they are not the only participants. Rather, this is an effort a whole neighborhood can at times be involved in. Accused witches in these suburbs of Port Vila are held captive in their neighborhood and the righteous people of the community legitimately beat them up over several days, in order to get them to tell the truth and confess. In neighborhood trials, imitating Western court cases, the individual suspected of evil is confronted with intent, motive, and circumstantial evidence (see Rio 2014). The direction the witch hunt takes in this Christian context is ambiguous. For outsiders, it may look like punishment or vengeance, but for relatives of the accused it is about separating the good from the evil so as to restore moral integrity and balance in the person. As such, it is first and foremost an act of order and purity, and in the process, the patient should be relieved of demons whereas witches should be exorcised or killed. Christianity's language of sacrifice thereby places itself into and transforms a social ontology that holds sorcery to be a fundamental underlying, constitutional category of social forces.

Witchcraft and sorcery in Port Vila today is thus fundamentally Christian, more specifically Pentecostal. In the discourses about healing and spiritual warfare one can see worries about a "heathen" past where spirits from "taem bifoa" (the past) or from foreign places emerge in new 
disguises, and one can detect a will for another future, where success, material and spiritual, will remove the fear of evil. Establishing protective borders against evil is crucial for social life in Port Vila. These aspects of the universalism of Pentecostal demonology have been widely described from all corners of the world. But Pentecostal healing ministries are also premised on a basis of local engagement. They are popular movements that take seriously the underlying social predicaments of the congregation but not by turning to historical or social conventions about what these predicaments are. Their popular power rather comes from redefining the spiritual and interhuman realm altogether. Their language of "warfare," "spiritual mapping," and "discernment" reveal their intense activity of renaming and reorganizing the inventories of the spiritual realms. People in Port Vila, coming from various islands of the archipelago as they do, used to differentiate between for instance people with magical skills and people who unconsciously embodied cannibalistic desires, between ancestor spirits who had been safely transported to their origin place after death and those who hadn't, between many different remedies such as stones for producing pigs and other stones that would kill people and destroy crops. It was the work of the diviner to address the multiplicity of signs and to create order and remedy out of the multitude. If you ask people in the Pentecostal churches today they will tell you that all this differentiation was itself part of the problem of evil, as was the idea that people from the different areas of the country used to live according to their own "law". The figure of the diviner, merely through his work of disentangling the multiplicity, is now also seen as instead entangling himself into the evil of the multiplicity. It appeals strongly to them that they can now subject all these differential aspects of their past to a unitary and universal cure.

\section{Notes}

1. "Sperem rod" means, literally, "spearing the road," indicating youth just walking up and down the street.

2. Kava is an intoxicating drink prepared from the roots of the Piper Methysticum plant.

3. Eriksen and Andrew (2010) reports on over 50 new Pentecostal churches in Port Vila.

4. Eriksen and Rio have done fieldwork together in Port Vila during repeated visits in 1999, 2000, 2006, 2010, and 2014. 
5. It is mostly women who operate as healers. With a few exceptions of adolescent boys, we never heard of male churchly healers.

6. We are here talking about Ambrym in the mid-1990s. Ambrym today might, and most probably is, part of a slightly different religious landscape, with an increasing presence of Pentecostal churches.

\section{REFERENCES}

Barker, J. 1990. "Encounters with Evil: Christianity and the Response to Sorcery Among the Maisin of Papua New Guinea". Oceania 61 (2): 139-155.

Dalton, D. 2007. "When is it Moral to be a Sorcerer", The Anthropology of Morality in Melanesia and Beyond, 39-55. Aldershot, England: Ashgate.

Dawson, N.R. 2010 'The Coroner's Report. Inquest into the Cause of Death of John Bule', Post Mortem Case No 29 of 2009. Vanuatu Supreme Court Archives.

Englund, H. 2004. "Cosmopolitanism and the Devil in Malawi”. Ethnos 69 (3): 293-316.

Eriksen, A. forthcoming "Going to Pentecost. How to Study Pentecostalism, in Melanesia for example" In Journal of the Royal Anthropological Institute.

-. 2009a. "New Life': Pentecostalism as Social Critique in Vanuatu”. Ethnos 74 (2): 175-198.

- 2009b. "Healing the Nation: In Search of Unity through the Holy Spirit in Vanuatu." Social Analysis 53 (1): 67-81.

- 2008. Gender, Christianity and Change, an Analysis of Social Movements in North Ambrym. Aldershot: Ashgate.

- 2005. The Gender of the Church: Conflicts and Social Wholes on Ambrym. Oceania 75 (3): 284-300.

Eriksen, A. and R. Andrew. 2010. "Churches in Port Vila." Report to the Vanuatu Cultural Centre. http://www.google.no/url? sa=t\&rct=j\&q=\&esrc $=\mathrm{s} \&$ frm $=1 \&$ source $=$ web \&cd $=1 \& v e d=0$ ahUKEwi_v7eQ_ZnKAhViw3IKH bEsCEEQFggmMAA\&url=http\%3A\%2F\%2Fgenpent.b.uib.no\%2Ffiles\%2F20 12\%2F11\%2FChurches-in-Port-Vila-ferdig.pdf\&usg=AFQjCNEwbAAiVrKm comldvj_67-HMxuNFQ\&bvm=bv.110151844,d.bGQ

Fortune, R.F. 1932. Sorcerers of Dobu. London: George Routledge \& Sons.

Geschiere, Peter. 2013. Witchcraft, Intimacy and Trust: Africa in Comparison. Chicago: Chicago University Press.

Hocart, A.M. 1925. "Medicine and Witchcraft in Eddystone of the Solomons." The Journal of the Royal Anthropological Institute of Great Britain and Ireland 55: 229-270.

Jorgensen, D. 2005. "Third Wave Evangelism and the Politics of the Global in Papua New Guinea: Spiritual Warfare and the Recreation of Place in Telefolmin.” Oceania 75 (4): 444-461. 
Layard, J.W. 1930. Malekula: "Flying Tricksters, Ghosts, Gods, and Epileptics". The Journal of the Royal Anthropological Institute of Great Britain and Ireland 60: 501-524.

MacDonald, F. 2015. 'Lucifer is Behind Me': The Diabolisation of Oksapmin Witchcraft as Negative Cosmological Integration. The Asia Pacific Journal of Anthropology 16 (5): 464-480.

Malinowski, Bronislav. 1926. Crime and Custom in Primitive Society. London: Keegan Paul.

Meyer, B. 1999. Translating the Devil: Religion and Modernity among the Ewe in Ghana. Edinburgh: Edinburgh University Press.

Mitchell, Jean. 2011. “'Operation Restore Public Hope': Youth and the Magic of Modernity in Vanuatu." Oceania 81 (1): 36-51.

Newell, Sasha. 2007. "Pentecostal Witchcraft: Neoliberal Possession and Demonic Discourse in Ivoirian Pentecostal Churches." Journal of Religion in Africa 37 (4): 461-490.

O'Neill, K.L. 2010. City of God: Christian Citizenship in Post-war Guatemala. University of California Press.

Rio, Knut M. 2002. "The Sorcerer as an Absented Third Person: Formations of Fear and Anger in Vanuatu." Social Analysis 46: 129-154.

- 2011. "Policing the Holy Nation: The State and Righteous Violence in Vanuatu." Oceania 81 (1): 51-72.

- 2014. 'A shared Intentional Space of Witch-Hunt and Sacrifice.' Ethnos, 79(3): 320-341.

Rio, Knut, and Annelin Eriksen. 2013. "Missionaries, Healing and Sorcery in Melanesia: A Scottish evangelist in Ambrym Island, Vanuatu." History and Anthropology 24 (3): 398-418.

Robbins, J. 2004. Becoming Sinners: Christianity and Moral Torment in a Papua New Guinea Society. Berkeley: University of California Press.

Robbins, Joel. 2009. "Pentecostal networks and the spirit of globalization: On the social productivity of ritual forms." Social Analysis 53 (1): 55-66.

Russell, J.B. 1986. Lucifer: The Devil in the Middle Ages. Ithaca, NY: Cornell University Press.

-1987. The Devil: Perceptions of Evil from Antiquity to Primitive Christianity. Ithaca, NY: Cornell University Press.

Stephen, Michele (ed.). 1987. Sorcerer and Witch in Melanesia. Melbourne: Melbourne University Press.

Thorarensen, Hildur. 2011. "Heal, Pray, Prosper: Practice and Discourse within a Local Pentecostal Church in Vanuatu." M.A. Thesis, University of Bergen.

Trnka, Susanna. 2011. "Re-Mythologizing the State: Public Security, 'the Jesus Strategy', and the Fiji Police." Oceania 81: 72-88. 


\section{Authors' Biography}

Annelin Eriksen is Professor at the Department of Social Anthropology, University of Bergen, where she leads a project on Gender and Pentecostalism. She has worked since 1995 in Vanuatu, first on Ambrym and later also in Port Vila. Her work deals with social and cultural change, Christianity and gender relations. Her publications include Gender, Christianity and Change in Vanuatu: An Analysis of Social Movements in North Ambrym (2008), New Life: Pentecostalism as Social Critique in Vanuatu (2009) and Contemporary Religiosities: Emergent Socialities and the Post-Nation State (co-edited with Bruce Kapferer and Kari Telle; Berghahn, 2010).

Knut Rio is Professor of Social Anthropology at the University of Bergen, Norway, and is responsible for the ethnographic collections at the Bergen University Museum. He has worked on Melanesian ethnography since 1995, with fieldwork in Vanuatu. His work on social ontology, production, ceremonial exchange, witchcraft and art in Vanuatu has resulted in journal publications and the monograph The Power of Perspective: Social Ontology and Agency on Ambrym Island, Vanuatu (2007). He has also co-edited Hierarchy. Persistence and Transformation in Social formations (with Olaf Smedal, 2009), Made in Oceania. Social Movements, Cultural Heritage and the State in the Pacific (with Edvard Hviding, 2011), and The Arts of Government: Crime, Christianity and Policing in Melanesia (with Andrew Lattas, 2011).

Open Access This chapter is licensed under the terms of the Creative Commons Attribution 4.0 International License (http://creativecommons.org/licenses/by/4.0/), which permits use, sharing, adaptation, distribution and reproduction in any medium or format, as long as you give appropriate credit to the original author(s) and the source, provide a link to the Creative Commons license and indicate if changes were made.

The images or other third party material in this chapter are included in the chapter Creative Commons license, unless indicated otherwise in a credit line to the material. If material is not included in the chapter Creative Commons license and your intended use is not permitted by statutory regulation or exceeds the permitted use, you will need to obtain permission directly from the copyright holder.

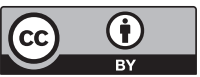

